\title{
IPR 126 white oat forage potential under free growth, cutting and grazing at two management heights
}

\author{
Marcela Abbado Neres ${ }^{1}$, Deise Dalazen Castagnara ${ }^{2}$, Paulo Sérgio Rabello de Oliveira ${ }^{1}$, \\ Elir de Oliveira ${ }^{3}$, Clóves Cabreira Jobim ${ }^{4}$, Tamara Taís Tres ${ }^{5}$, Eduardo Eustáquio Mesquita ${ }^{1}$
}

${ }^{1}$ Centro de Ciências Agrárias - Universidade Estadual do Oeste do Paraná, PR.

2 Programa de Doutorado em Produção Vegetal, Universidade Estadual do Oeste do Paraná - Unioeste, PR.

3 Instituto Agronômico do Paraná - lapar. Rodovia PRT 163, km 188 - Cruzinhas, Caixa Postal 2 - 85825000.

4 Universidade Estadual de Maringá - UEM. Av. Colombo, 1790 - Jardim Universitário, Maringá, PR, 87020900.

5 Programa de Mestrado em Pastagem e Forragicultura - Universidade Estadual do Maringá - UEM, Maringá, PR.

\begin{abstract}
The experiment was carried out to evaluate the structural characteristics, biomass accumulation, chemical composition and in vitro digestibility of dry matter and crude protein of white oat (Avena sativa L. IPR 126) under different management systems. Grazing, cut at two heights $(15$ and $20 \mathrm{~cm})$ and free growth were all evaluated in three periods (July, August and September) with a 28-day average interval between evaluations. In the free growth system, samples at 15 and $20 \mathrm{~cm}$ were also taken at the intervals chosen for cutting and grazing. The experimental design was in randomized blocks with three replications, arranged in a $3 \times 2$ factorial split plot design over time; systems of management and heights were the factors of plots, and time was taken as subplot. There was higher straw production under free growth, but, with decreased chemical quality from the first to the second period and from the second to the third one, with $236.4,172.5$, and $91.4 \mathrm{~g} / \mathrm{kg}$ crude protein values, respectively. Regarding cutting and grazing systems, they showed structural changes in tillering, which was favored by the cut, but with some reduction in the periods. Nutritional quality values were close to cutting and grazing with high crude protein content (216.6 g/kg), adequate neutral detergent fiber $(535.4 \mathrm{~g} / \mathrm{kg})$ content and high in vitro digestibility of dry matter $(826.3 \mathrm{~g} / \mathrm{kg})$. Management heights promoted few changes in the characteristics evaluated. After the third period, cutting and grazing systems showed no suitable residual straw for ground covering and set a summer crop under no-tillage system, with $738.39 \mathrm{~kg} / \mathrm{ha}$ of residual dry matter on average.
\end{abstract}

Key Words: apical meristem, Avena sativa, in vitro dry matter digestibility, white oat nutritional quality

\section{Introduction}

In southern Brazil, spring-summer and autumn-winter transitions, when grasses are completing their development in each season and the next ones are not adapted for grazing, are considered critical periods for animal feeding in systems of pasture production. Food shortage in this period leads to drops in milk production and less fundraising by the producer (Rocha et al., 2007).

The use of annual grasses as pasture in cool season is an alternative to forage production in rotation systems with summer crops, in order to supply the food deficit caused by low temperatures, frosts and low light during autumn and winter (Roso et al., 1999). The possibility of using winter forage on cattle weight gain and feeding of dairy cows in the winter months and traditional agriculture areas have brought crop-livestock integration activity, which can result in a better use of the farm power (Bortolini et al., 2004). The white oat stands out for its potential to feed animals and it can also become an important component in agricultural production systems, contributing to greater sustainability of these systems, since it allows crop-livestock integration in no-tillage system (Primavesi et al., 2004).

Grasses that are kept under different heights have different levels of forage supply, which may affect yield and pasture quality; therefore, there must be an adjustment in forage supply to increase quality, yield and better balance of botanical composition of pasture (Ido, 1997).

However, the input of a great amount of waste after cutting or grazing to the soil is one of the main points of no-tillage systems in crop-livestock integration, since it influences directly the summer crops as there is weed control, maintenance of soil moisture, erosion reduction, structuring and aggregation of soil.

Thus, this study aimed at evaluating the dry matter production, biomass accumulation, structural characteristics, 
chemical composition and in vitro digestibility of dry matter and crude protein of IPR 126 white oat (Avena sativa) under several management forms.

\section{Material and Methods}

The experiment was carried out under field conditions at the Experimental Farm Antonio Carlos dos Santos Pessoa, on May $30^{\text {th }}$, 2009, in an experimental area from the Universidade Estadual do Oeste do Paraná in Marechal Cândido Rondon Campus - Paraná, with the following coordinates: $24^{\circ} 19^{\prime} \mathrm{S}$ latitude, $54^{\circ} 01 \mathrm{~W}$ longitude and $392 \mathrm{~m}$ altitude. According to Koppen, the local weather is classified as $\mathrm{Cfa}$, subtropical, with well distributed rainfalls during the year and hot summers. Temperatures of the coldest quarter range between 17 and $18{ }^{\circ} \mathrm{C}$, between 28 and $29^{\circ} \mathrm{C}$ in the warmest quarter and between 22 and $23^{\circ} \mathrm{C}$ yearly. According to the average results at the end of the year, for this region, the rainfalls range from 1,600 to $1,800 \mathrm{~mm}$, while the wettest quarter ranges from 400 to $500 \mathrm{~mm}$ and the driest quarter ranges from 250 to $350 \mathrm{~mm}$ (IAPAR, 2006).

The studied soil is classified as Oxisol (EMBRAPA, 2006), with the following chemical characteristics: $\mathrm{pH}$ in water - 5.70; P (Mehlich) - $20.20 \mathrm{mg} / \mathrm{dm}^{3}$; K (Mehlich) $0.37 \mathrm{cmol}_{\mathrm{c}} / \mathrm{dm}^{3} ; \mathrm{Ca}^{2+}\left(\mathrm{KCl} 1 \mathrm{~mol} \mathrm{~L}^{-1}\right)-4.87 \mathrm{cmol}_{\mathrm{c}} / \mathrm{dm}^{3}$; $\mathrm{Mg}^{2+}(\mathrm{KCl} 1 \mathrm{~mol} / \mathrm{L})-0.58 \mathrm{cmol}_{\mathrm{c}} / \mathrm{dm}^{3} ; \mathrm{Al}^{3+}(\mathrm{KCl} 1 \mathrm{~mol} / \mathrm{L})-$ $\mathrm{cmol}_{\mathrm{c}} / \mathrm{dm}^{3} 0.00 ; \mathrm{H}+\mathrm{Al}$ (calcium acetate $0.5 \mathrm{~mol} / \mathrm{L}$ ) $6.48 \mathrm{cmol}_{\mathrm{c}} / \mathrm{dm}^{3} ; \mathrm{SB}-5.82 \mathrm{cmol}_{\mathrm{c}} / \mathrm{dm}^{3} ; \mathrm{CTC}-12.32 \mathrm{cmol}_{\mathrm{c}} / \mathrm{dm}^{3}$ $\mathrm{V}-57.32 \%$ organic matter (Method Boyocus) $-25.29 \mathrm{~g} / \mathrm{dm}^{3}$ and clay - $65 \%$.

The experimental design was in randomized blocks with three replications, arranged in a $3 \times 2$ factorial split plot over time; in a way that the systems of management and heights were the factors of plots, and time was taken as subplot. Experimental plots had dimensions $12 \times 30 \mathrm{~m}\left(360 \mathrm{~m}^{2}\right)$.

The treatments consisted of five methods to manage IPR 126 white oat (Avena sativa L.): grazing with $15 \mathrm{~cm}$ residual; grazing with $20 \mathrm{~cm}$ residual; cutting with $15 \mathrm{~cm}$ residual, cutting with $20 \mathrm{~cm}$ residual and free growth with an evaluation at $15 \mathrm{~cm}$ and $20 \mathrm{~cm}$. Even in free-growth treatments, evaluations were obtained through sampling cuts $\left(1 \mathrm{~m}^{2}\right)$ at 15 and $20 \mathrm{~cm}$ in the same evaluation period of the other treatments (before animals entry or forage cutting). This is due to the opportunity to evaluate white oat when grazing or cutting will be postponed. Cuts or grazing occurred in three periods: July $25^{\text {th }}$, August $24^{\text {th }}$ and September $21^{\text {st }}$, 2009 . The resting period was on average of 28 days, to allow sprouting of white oat at an average height of $35 \mathrm{~cm}$ in cutting and grazing treatments. There was high precipitation during the experimental period (Figure 1).

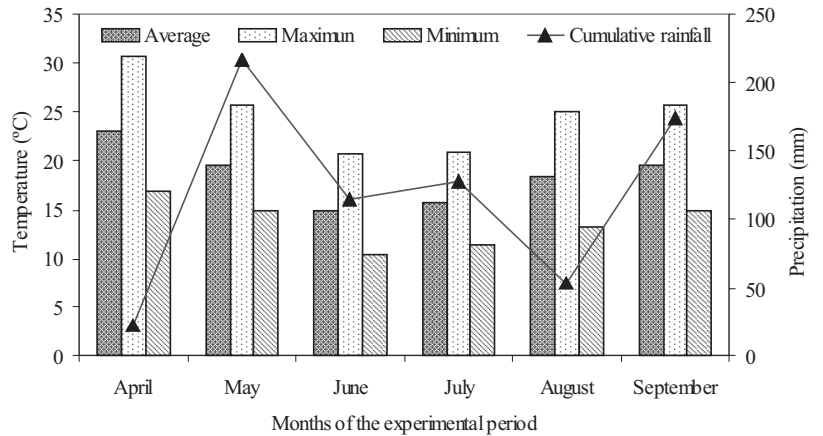

Source: Automatic Weather Station of Marechal Cândido Rondon Paraná, 2009

Figure 1 - Maximum, minimum and average temperatures and cumulative rainfall during the experimental period.

The sowing of IPR 126 white oat was carried out on May, $30^{\text {th }}$, with a precision seeder coupled to a tractor with $80 \mathrm{~kg} / \mathrm{ha}$ seeds density, distributed in rows with $0.17-\mathrm{m}$ distance, without fertilizer application. At 55 days after crop emergence, when it reached the cut height (35 $\mathrm{cm}$ average), the first cuttings or grazing were done. Dairy cows with almost $450 \mathrm{~kg}$ live weight were used in grazing, distributed in paddocks in order to graze until the residual heights were with 15 and $20 \mathrm{~cm}$. This always happened at milking intervals (8:30 to 17:00 hours). On average, three cows were used per paddock with an average permanence time of three grazing days. For cutting treatments, mechanical reaper was used, coupled to a tractor set at the determined cutting heights (15 and $20 \mathrm{~cm}$ ), always on the last day of the grazing treatment. Three nitrogen fertilizations were performed in all treatments: 30 days after sowing, after the first period and after the second period with $40 \mathrm{~kg} /$ ha Nitrogen $(\mathrm{N})$ as urea.

The presence of rust (Puccinia coronata f.sp. avenae Fraser \& Led.), a typical disease in oats, was observed between the second and third cuts when plants were beginning to bloom. However, throughout the whole trial period, pests, weeds or other diseases that damage crops development were not observed. Once plants reached the ideal grazing or cutting heights $(35 \mathrm{~cm})$, measurements were performed on structural characteristics, sampling collection to determine dry matter yield, chemical composition and in vitro digestibility of dry matter and crude protein. After each application of managements, three samples were taken from each paddock by cutting close to the soil, using a $1-\mathrm{m}^{2}$ metal square to determine determine the waste after cutting, grazing and free growth. These samples were weighed, oven-dried ( $55^{\circ} \mathrm{C}, 72$ hours) and weighed again.

The structural characteristics evaluated included: crops canopy, apical meristem height, tiller number, leaf/stem 
ratio, final leaf length and number of leaves per tiller. In order to obtain the canopy height of plants, ten points were measured in each plot with a $100-\mathrm{cm}$ graduated ruler. Measurements on the apical meristem height were collected at ten points in each plot with a $100-\mathrm{cm}$ graduated ruler.

A metallic square $\left(1 \mathrm{~m}^{2}\right)$ was used to record the number of tillers, which was randomly thrown twice in each plot and then all tillers inside it were counted. To determine leaf/ stem ratio, a manual separation and a drying method were used, in which 50 -g samples were collected and separated into leaves and stems. They were packed in paper bags and dried at $55^{\circ} \mathrm{C}$ for 72 hours in oven with forced ventilation. The leaf/stem ratio (L/S) was obtained from the ratio between dry weight of leaves and dry weight of stems. The final leaves length was obtained by measuring the distance from the top to the ligule of each fully expanded leaf of each tiller. The number of leaves per tiller was obtained by removing and counting the leaf slices of each tiller.

Samples were also collected for chemical evaluation and determination of in vitro digestibility of dry matter and crude protein. These samples were obtained before every animal grazing, cutting and free growth. Samples were always taken in the same period of the other treatments using a metallic square $\left(1 \mathrm{~m}^{2}\right)$ that was randomly thrown in each plot (3 samples) and all plants inside it were collected with a sickle. These samples were taken to the laboratory of Animal Nutrition and weighed to determine green matter production. Sub-samples were put in an oven of forced air at $55^{\circ} \mathrm{C}$ for 72 hours and weighed to determine dry matter. They were milled in a knife grinder with 1-mm sieve for further analyses of dry matter (DM) and crude protein (CP) according to AOAC (1990), neutral detergent fiber (NDF), acid detergent fiber (ADF) according to Van Soest et al. (1991) and lignin and cellulose according to Silva \& Queiroz (2006).

The in vitro digestibility of dry matter and crude protein determinations were recorded according to the technique described by Tilley \& Terry (1963), adapted to an
Artificial Rumen, as described by Holden (1999). Data were statistically analyzed using the program SAEG (Sistema para Análises Estatísticas, version 7.0) and treatments were compared by the Tukey test at $5 \%$ probability.

\section{Results and Discussion}

There was significant effect of management practices (cutting, grazing and free growth), periods (July, August and September) and management $\times$ height and management $\times$ period interactions $(\mathrm{P}<0.01)$ on dry matter production. in the interaction of management $\times$ height (Table 1 ), dry matter production was higher in both heights when IPR 126 white oat was not under any management, while for cutting and grazing managements, higher dry matter production $(\mathrm{P}<0.05)$ was obtained at $20 \mathrm{~cm}$ for grazing and there was no difference between heights on cutting treatment (Table 1 ). These results are already expected and are according to those obtained by Bortolini et al. (2005), who observed that non-grazed plants also had higher dry matter production, when evaluating white oat under different grazing periods.

Regarding heights in each management system, there was higher dry matter production in grazing at $20 \mathrm{~cm}$, while for cutting, no differences were observed between heights, and with no management, the highest production was achieved at $15 \mathrm{~cm}$ (Table 1).

In the unfolding of the interaction of management $x$ period(Table 2), there were differences between managements in the second and third cut, with higher dry matter production when no management was applied to white oat. But, when periods were compared in each management, a higher production was observed in the first and second periods. For the absence of management, the highest dry matter production was observed in the third period, followed by the second and first periods, according to dry matter accumulation as a function of time (Table 2). Reis et al. (1992) worked with black oat under irrigation and recorded a dry matter production of $1714 \mathrm{~kg} / \mathrm{ha}$.

Table 1 - Dry matter production and residual straw (average of three cuts) of IPR 126 white oat under three management strategies and two heights of cutting or grazing

\begin{tabular}{|c|c|c|c|c|c|c|c|}
\hline \multirow{3}{*}{ Management } & \multicolumn{3}{|c|}{ Dry matter production (kg/ha) } & \multicolumn{3}{|c|}{ Residual straw (kg/ha) } & \multirow{3}{*}{$\begin{array}{c}\text { DM (g/kg) } \\
\text { Periods }\end{array}$} \\
\hline & \multicolumn{3}{|c|}{ Heights } & \multicolumn{3}{|c|}{ Heights } & \\
\hline & $15 \mathrm{~cm}$ & $20 \mathrm{~cm}$ & Mean & $15 \mathrm{~cm}$ & $20 \mathrm{~cm}$ & Mean & \\
\hline Grazing & 1159.63Bb & 1269.63bA & $1214.63 b$ & $929.13 \mathrm{bB}$ & $1116.73 \mathrm{bA}$ & $1022.93 b$ & $1^{\text {st }} 123.8 \mathrm{c}$ \\
\hline Cutting & $1178.11 \mathrm{bA}$ & $1170.58 \mathrm{bA}$ & $1174.34 b$ & $964.90 \mathrm{bA}$ & 965.69с A & $965,09 b$ & $2^{\text {nd }} 150.0 \mathrm{~b}$ \\
\hline $\begin{array}{l}\text { Free growth } \\
\text { CV (\%) }\end{array}$ & 2920.77 aA & $\begin{array}{c}2640.81 \mathrm{aB} \\
10.28\end{array}$ & $2780.79 a$ & 2920.77 aA & $\begin{array}{c}2640.81 \mathrm{aB} \\
9.41\end{array}$ & $2780,79 a$ & $\begin{array}{c}3^{\text {rd }} 185.5 a \\
11.71\end{array}$ \\
\hline
\end{tabular}

Means followed by same lowercase letter in the row and uppercase letter in column do not differ by Tukey test at $5 \%$ probability. $\mathrm{CV}$ - coefficient of variation. 
According to the studied evaluations from this experiment, IPR 126 white oat showed $1375.93 \mathrm{~kg} / \mathrm{ha}$ mean values at the first harvest with some decrease in the following periods for cutting and grazing managements and accumulation on free growth. Such decrease in dry matter production during the evaluation periods was also observed in cutting and grazing management practices by Moreira et al. (2007), who worked with winter forage, irrigated under grazing. They assumed that this decrease is caused by the advanced stage of plants development, which caused the elimination of apical meristems and damage to a new sprouting. However, there was no elimination of apical meristem from the first to the second and from the second to third periods at the heights measured (15 and $20 \mathrm{~cm}$ ) (Table 4), once it increased at each cutting or grazing.

Bortolini et al. (2004) analyzed forage potential for white oat, wheat, triticale, black oat, rye and barley. Aiming at their use in double purpose conditions, they also observed some decrease in dry matter production for genotypes of rye and barley after the first cut, so they stated that the differences in answers for each cereal and/or genotype is mainly due to the plants efficiency to produce new tillers after cuts. The dry matter percentage was low in the first period $(123.8 \mathrm{~g} / \mathrm{kg})$, increased in the second $(150.0 \mathrm{~g} / \mathrm{kg})$ and reached $185.5 \mathrm{~g} / \mathrm{kg}$ in the third period (Table 1 ).

According to Primavesi et al. (2001), total dry matter (DM) production increases with plant age, but, at the same time, there is a decrease of its nutritional value; hence treatment without management had higher dry matter production (Table 1), though decreased nutritive value (Table 6), which may favor slow straw decomposition. This is required in no-tillage systems due to greater soil coverage time, thus preventing growth of weeds and promoting its moisture maintenance. Thus, one can see the great importance of long-life materials in dry matter yield, which can be managed for grazing, cutting or hay/ straw production to soil coverage. The major challenge in integrated systems is finding an intermediate level of dry matter production that benefits the summer crops under no-tillage system, regarding livestock during grazing period to ensure a high productivity in the system.

Straw production was influenced by soil management, heights, periods and interactions of management $\times$ height and management $\times$ period $(\mathrm{P}<0.01)$. In the unfolding of the interaction of management $\times$ height (Table 1 ), the highest straw production was observed when there was no management practices to white oats in both heights and average values.

Demetrio (2009) evaluated several oat genotypes aiming the straw production in a no-tillage system. The author obtained 907; 1,644 and 1,692 kg/ha dry matter production for IPR 126 white oat in three cuts with $2,121 \mathrm{~kg} / \mathrm{ha}$ average production and these responses were higher than the ones obtained in this trial at the cutting management (1,174 kg/ha).

According to Kluthcouski \& Yokoyama (2003), the resulting mulch of crop wastes is generally inadequate to a complete coverage and soil protection and can cause problems to the no-tillage system efficiency. When Saraiva \& Torres (1993) evaluated some cover crops species, they found that 1,$000 ; 2,000$ and $4,000 \mathrm{~kg} /$ ha dry matter from plant waste covered approximately 20,40 and 60 to $70 \%$ of soil surface, respectively, although structural characteristics of forage species could interfere on this coverage percentage. The same authors also concluded that, at least 7,000 kg/ha straw dry matter are needed for a complete coverage of soil surface.

Boller \& Gamero (1997) observed that the partial use of winter crops biomass for animal feeding can balance energy and improve the economic performance of conservationist tillage systems. Choosing the best system to set a crop rotation program must take several factors into account, specially the main system goal. For soil coverage and/or initial straw supply, choosing species and cultivars that produce high dry matter amounts with high leaf/stem ratio allows a management that postpones decomposition.

Table 2 - Dry matter and residual straw production of white oat under three management strategies in different periods

\begin{tabular}{|c|c|c|c|c|c|c|}
\hline \multirow{3}{*}{ Management } & \multicolumn{3}{|c|}{ Dry matter production ( $\mathrm{kg} / \mathrm{ha})$} & \multicolumn{3}{|c|}{ Residual production (kg/ha) } \\
\hline & \multicolumn{3}{|c|}{ Periods } & \multicolumn{3}{|c|}{ Periods } \\
\hline & $1^{\text {st }}$ & $2^{\text {nd }}$ & $3^{\text {rd }}$ & $1^{\text {st }}$ & $2^{\text {nd }}$ & $3^{\text {rd }}$ \\
\hline Grazing & $1426.25 \mathrm{aA}$ & $1286.00 \mathrm{aB}$ & 931.64bB & $1212.79 b A$ & $1123.41 \mathrm{bA}$ & $732.59 b B$ \\
\hline Cutting & $1316.73 \mathrm{aA}$ & $1282.87 \mathrm{aB}$ & $923.43 \mathrm{bB}$ & $1134.80 \mathrm{bA}$ & $1016.28 \mathrm{bA}$ & $744.20 \mathrm{Bb}$ \\
\hline Free growth & $1384.82 \mathrm{aC}$ & $2345.10 \mathrm{aB}$ & $4612.45 \mathrm{aA}$ & $1384.82 \mathrm{aA}$ & $2345.10 \mathrm{aA}$ & $4612.45 \mathrm{aB}$ \\
\hline Mean & 1375.93C & 1637.99B & $2155.84 a$ & $1244.14 \mathrm{C}$ & 1494.93B & $2029.75 \mathrm{~A}$ \\
\hline CV (\%) & & 10.28 & & & 9.41 & \\
\hline
\end{tabular}

Means followed by same lowercase letter in row and uppercase letter in column do not differ by Tukey test at $5 \%$ probability. $\mathrm{CV}$ - coefficient of variation. 
In the unfolding of the interaction of management $x$ period, greater biomass accumulation was observed when there was no management practice in all periods; however, when periods were compared in each management, higher yields were obtained with the first and second periods in all managements. According to Gomide (1994), the feeding of green matter under grazing is primarily affected by forage availability, but also by vegetation structure such as density, height and leaf/stem ratio.

For forage canopy height (Table 3), there was a significant effect of managements, heights, periods and interactions of management $\times$ height, management $\times$ period and height $\times$ period $(\mathrm{P}<0.01)$. During the interaction of managements $\times$ heights, the highest heights (evaluation) of forage canopies were observed when there was no management practice, as well as no difference among heights. For cutting and grazing managements, higher canopy heights were obtained at $20 \mathrm{~cm}$.

In the interaction of height $\times$ period, there were no differences among heights in the first period, while for the second and third periods, the greatest canopy heights were obtained at $20 \mathrm{~cm}$. When considering periods for both heights, the highest heights of forage canopy were observed in third period, followed by the second and first periods (Table 3).

Higher canopy heights were observed in grazing and cutting at $20 \mathrm{~cm}$ and can be explained by sprouting starts from a greater height. Mello \& Pedreira (2004) worked with different grazing intensities and observed variation in the average height of grass on all grazing periods, so they attributed the fact to the differences between post-grazing heights as the canopy always started sprouting from predetermined forage masses. This result can also be explained, since there is less removal of leaf portion in grazing at $20 \mathrm{~cm}$, remaining the amount with the highest photosynthetic capacity (Bremm et al., 2008). Leaf removal is higher in cutting at $15 \mathrm{~cm}$, although with no differences $(\mathrm{P}>0.05)$ for leaf/stem ratio for the studied heights.

Most published papers on tillering with oats have been carried out aiming at evaluating seeds production (Nakagawa et al., 2000; Reichardt et al., 2008). Tillering in forage grasses has been described as the most important feature to establish productivity of these crops (Simon \& Lemaire, 1987). For tiller number, there was interaction between growing seasons and management systems, since the cutting management system has shown higher number of tillers $(\mathrm{P}<0.05)$ when compared with other systems (Table 4) in all studied periods.

On grazing system, values were lower than those in other systems of the first and second periods, while the third period proved to be superior to free growth. There was some reduction on number of tillers $(\mathrm{P}<0.05)$ in all management systems and evaluation period, with an average of 761.28 tillers $/ \mathrm{m}^{2}$ in the first one, 500.67 in the second and 374.44 tillers $/ \mathrm{m}^{2}$ in the last evaluation period. Regarding the managed heights, the averages were 570.89 tillers $/ \mathrm{m}^{2}$ at $15 \mathrm{~cm}$ and 520.04 tillers $/ \mathrm{m}^{2}$ at $20 \mathrm{~cm}$,

Table 3 - Forage canopy height (cm) of white oat in interaction management heights, management systems and canopy height (cm) of white oat in interaction of management heights and evaluation periods

\begin{tabular}{|c|c|c|c|c|c|c|c|}
\hline \multirow[t]{2}{*}{ Management } & \multicolumn{3}{|c|}{ Heights } & \multirow[t]{2}{*}{ Periods } & \multicolumn{3}{|c|}{ Heights } \\
\hline & $15 \mathrm{~cm}$ & $20 \mathrm{~cm}$ & Means & & $15 \mathrm{~cm}$ & $20 \mathrm{~cm}$ & Means \\
\hline Grazing & $34.57 \mathrm{bB}$ & $37.55 \mathrm{bA}$ & $36.06 \mathrm{~b}$ & $1^{\text {st }}$ & 29.88cA & 29.75 с A & $29.82 c$ \\
\hline Cutting & $34.60 \mathrm{bB}$ & $39.51 \mathrm{bA}$ & $37.06 \mathrm{~b}$ & $2^{\text {nd }}$ & $42.56 \mathrm{bB}$ & $48.44 \mathrm{bA}$ & $44.17 \mathrm{~b}$ \\
\hline Free growth & $64.17 \mathrm{aA}$ & $64.56 \mathrm{aA}$ & $64.36 \mathrm{a}$ & $3^{\text {rd }}$ & $49.07 \mathrm{aB}$ & $53.02 \mathrm{aA}$ & $51.04 \mathrm{a}$ \\
\hline CV (\%) & 4.07 & & & & & & \\
\hline
\end{tabular}

Means followed by same lowercase letter in row and uppercase letter in column do not differ by Tukey test at $5 \%$ probability.

$\mathrm{CV}$ - coefficient of variation.

Table 4 - Number of tillers $/ \mathrm{m}^{2}$ in interaction of growth periods with management systems and number of tillers $/ \mathrm{m}^{2}$ in the interaction of management heights and different evaluation periods

\begin{tabular}{|c|c|c|c|c|c|c|c|}
\hline \multirow[t]{2}{*}{ Number of tillers } & \multicolumn{3}{|c|}{ Growth periods } & \multirow[t]{2}{*}{ Periods } & \multicolumn{2}{|c|}{ Heights } & \multirow[b]{2}{*}{ Mean } \\
\hline & $1^{\mathrm{st}}$ & $2^{\text {nd }}$ & $3^{\text {rd }}$ & & $15 \mathrm{~cm}$ & $20 \mathrm{~cm}$ & \\
\hline Grazing & 680.00 c A & $432.00 \mathrm{bB}$ & 353.33bC & $1^{\text {st }}$ & 794.44 & 728.11 & $761.28 b$ \\
\hline Cutting & $846.00 \mathrm{aA}$ & $600.00 \mathrm{aB}$ & $476.00 \mathrm{aC}$ & $2^{\text {nd }}$ & 524.00 & 477.33 & $500.50 \mathrm{a}$ \\
\hline Free growth & $757.83 \mathrm{bA}$ & $470.00 \mathrm{bB}$ & $294.00 \mathrm{cC}$ & $3^{\text {rd }}$ & 394.22 & 354.67 & $374.44 b$ \\
\hline Mean & 761.28 & 500.67 & 374.44 & & $570.89 \mathrm{~A}$ & $520.04 \mathrm{~B}$ & \\
\hline CV (\%) & & & & 7.03 & & & \\
\hline
\end{tabular}

Means followed by same lowercase letter in row and uppercase letter in column do not differ by Tukey test at $5 \%$ probability.

$\mathrm{CV}$ - coefficient of variation. 
which showed that the shortest cuttings promoted tillering in IPR 126 white oats. When the tillering was evaluated in interaction of management heights and periods, they were superior in the first period when compared with the others.

For forage canopy height (Table 5), in the interaction of management $\times$ periods, there were no differences between managements $(\mathrm{P}>0.05)$ in the first period, with superior absence in white oat management in the second and third periods. When periods were compared in each management system, grazing and cutting, higher canopy heights were observed in the second and third periods, while greater height was observed in the third period in the absence of management, followed by the first and second periods (Table 5). There are few trials that evaluated structural characteristics of oat species at monocrop, which are influenced by soil and climatic conditions as well as the used management.

According to the interaction of management $\times$ period (Table 5), the variable height of apical meristem showed statistical difference between the second and third managements, so it was superior with the absence of management $(67.70 \mathrm{~cm})$, followed by grazing $(17.03 \mathrm{~cm})$. And when periods were compared, this variable was superior in the third period followed by the second and first one in all systems (Table 5). Present data contradict Briske \& Richards (1995), who stated that white oat is characterized by keeping the apical meristem close to soil surface until the beginning of reproductive phase. However, the apical meristem of plants was not removed at predetermined heights for cutting and grazing in this experiment, so there was a better sprouting.

On leaf/stem ratio (Table 5), in the management $\times$ period interaction, no period showed differences between managements. However, when periods in each management were compared, the first and second periods showed higher leaf/stem ratio, not differing from one another, but it was inferior only in the last one. These results are probably due to tillering stimulation, which tends to increase in defoliation in the early stages and to reduce in the later stages of plant development (Mundstock, 1999). Under rotational grazing system, the severe grazing pasture contributes to the most efficient use of available forage during the grazing period and, indirectly, reduces losses due to senescence and death of leaves in the remaining period subsequent to grazing. Overall, with temperature increase, plants started differentiation on apical meristem and elongating stem, which promoted L/S ratio decrease (Langer, 1963).

The characteristic of stem diameter, in the interaction of management $\times$ period, no difference between managements in the first period was found, but the second and third ones were superior in the absence of management. When compared among periods, this feature was higher in the first and second periods for managements and lower in their absence; however, in the third period, it was superior for grazing management and absence management and lower in cutting management (Table 5).

For final leaf length (Table 5), during the interaction of management $\times$ period, there were no differences in the first

Table 5 - White oat structural features under three management systems at different periods

\begin{tabular}{|c|c|c|c|c|c|c|}
\hline \multirow{3}{*}{ Management } & \multicolumn{3}{|c|}{ Forage canopy height $(\mathrm{cm})$} & \multicolumn{3}{|c|}{ Apical meristem height (cm) } \\
\hline & \multicolumn{3}{|c|}{ Period } & \multicolumn{3}{|c|}{ Period } \\
\hline & $1^{\text {st }}$ & $2^{\text {nd }}$ & $3^{\text {rd }}$ & $1^{\mathrm{st}}$ & $2^{\text {nd }}$ & $3^{\text {rd }}$ \\
\hline Grazing & $29.75 \mathrm{aB}$ & $39.77 \mathrm{bA}$ & $38.67 \mathrm{cA}$ & $0.81 \mathrm{aC}$ & $11.03 \mathrm{bB}$ & $17.03 \mathrm{bA}$ \\
\hline Cut & $29.79 a \mathrm{~B}$ & $40.55 \mathrm{bA}$ & $40.83 \mathrm{bA}$ & $0.82 \mathrm{aC}$ & $11.21 \mathrm{bB}$ & $14.72 \mathrm{bA}$ \\
\hline Free growth & $30.00 \mathrm{aC}$ & $66.87 \mathrm{aB}$ & $96.22 \mathrm{aA}$ & $0.81 \mathrm{aC}$ & $24.40 \mathrm{aB}$ & $67.70 \mathrm{aA}$ \\
\hline CV $(\%)$ & & 4.07 & & & 19.18 & \\
\hline Grazing & $4.55 \mathrm{aA}$ & $3.45 \mathrm{aA}$ & $1.75 \mathrm{aB}$ & $3.48 \mathrm{aA}$ & $3.49 \mathrm{bA}$ & $2.95 \mathrm{bA}$ \\
\hline Cut & $4.51 \mathrm{aA}$ & $3.85 \mathrm{aA}$ & $2.01 \mathrm{aB}$ & $3.41 \mathrm{aA}$ & $3.40 \mathrm{bA}$ & $3.02 \mathrm{bB}$ \\
\hline Free growth & $4.53 \mathrm{aA}$ & $2.91 \mathrm{aA}$ & $0.81 \mathrm{aB}$ & $3.44 \mathrm{aB}$ & $4.04 \mathrm{aAB}$ & $4.29 \mathrm{aA}$ \\
\hline \multirow[t]{2}{*}{ CV (\%) } & & 39.62 & & & 13.50 & \\
\hline & \multicolumn{3}{|c|}{ Leaf final length (cm) } & \multicolumn{3}{|c|}{ Number of leaves per tiller } \\
\hline
\end{tabular}

Means followed by the same lowercase letter in column and uppercase letter in the rows do not differ by Tukey test at $5 \%$ probability. $\mathrm{CV}$ - coefficient of variation. 
and third periods between managements; however this feature was higher for absence management in the second period. When periods were compared, the first one was lower in the absence of management and superior for grazing management only in the third period.

The number of leaves per tiller, in the interaction of management $\times$ period, showed significant difference only in the second and third periods and it was superior in the absence of management. Among the periods, it was superior in the first and second periods for cutting and grazing managements, but inferior for the absence of management. In the third period, it was superior in the absence of managements (Table 5).

Determining the forage potential for cultivar requires not only dry matter yield, but also the nutritional value for animals. For the variable crude protein (Table 6), in the unfolding of the interaction management $\times$ period, there was no difference between managements in the first cut. It was superior at the second and third period when white oats were submitted to some kind of management (cutting or grazing). According to the comparison within periods, this feature was superior in the first period of all systems and on grazing management of the second period, but, it was inferior in the others. The third period showed the lowest values that were even lower for the absence of management (Table 5).
Floss et al. (1985) recorded average contents of CP in oats from 180 to $250 \mathrm{~g} / \mathrm{kg}$ in the first cut and from 120 to $150 \mathrm{~g} / \mathrm{kg}$ in the second. The decrease of crude protein contents, in the highest heights, is explained by the greatest aging of part of available forage plus the greater fraction of senescent forage and higher stem ratio with an important development of structural tissues (Grise et al., 2001). Ferolla et al. (2008) worked with black oat and triticale under cutting and grazing. They observed that the crude protein content varied according to cropping seasons. This suggested that plants physiological stage is a determining factor of crude protein content, found in the studied species.

Neutral detergent fiber (Table 6), in the interaction of management $\times$ period, differed $(\mathrm{P}<0.05)$ among managements only in the third period and showed a higher answer in the absence of management. When periods were compared, the third one showed the highest responses. Cecato et al. (2001) studied nitrogen content in black oats cv. IAPAR 61 and recorded 408 and $492 \mathrm{~g} / \mathrm{kg}$ NDF in DM for the $1^{\text {st }}$ and $2^{\text {nd }}$ cuts, respectively. These values were lower than those ones obtained in this study; therefore, the author associates the higher NDF values in the second cut to the plants age with an increasing content of cell wall. This, certainly, explains the highest values observed in the third cut in this trial.

Table 6 - Chemical composition of white oat under three management strategies in different periods

\begin{tabular}{|c|c|c|c|c|c|c|}
\hline \multirow{3}{*}{ Management } & \multicolumn{3}{|c|}{ Crude protein (g/kg) } & \multicolumn{3}{|c|}{ Neutral detergent fiber (g/kg) } \\
\hline & \multicolumn{3}{|c|}{ Periods } & \multicolumn{3}{|c|}{ Periods } \\
\hline & $1^{\text {st }}$ & $2^{\text {nd }}$ & $3^{\text {rd }}$ & $1^{\text {st }}$ & $2^{\text {nd }}$ & $3^{\text {rd }}$ \\
\hline Grazing & $230.7 \mathrm{aA}$ & $225.6 \mathrm{aA}$ & 194.9aB & $529.8 \mathrm{aB}$ & $493.4 \mathrm{aB}$ & $596.4 \mathrm{bA}$ \\
\hline Cutting & $242.1 \mathrm{aA}$ & $210.0 \mathrm{aB}$ & $196.5 \mathrm{aB}$ & $513.3 \mathrm{aB}$ & $490.1 \mathrm{aB}$ & $589.5 \mathrm{bA}$ \\
\hline Free growth & $236.4 \mathrm{aA}$ & $172.5 \mathrm{bB}$ & $91.4 \mathrm{bC}$ & $521.5 \mathrm{aB}$ & $521.0 \mathrm{aB}$ & $690.8 \mathrm{aA}$ \\
\hline CV $(\%)$ & & 13.81 & & & 7.49 & \\
\hline Grazing & $303.7 \mathrm{aB}$ & $274.9 \mathrm{bC}$ & $388.5 \mathrm{bA}$ & $226.1 \mathrm{aA}$ & $218.6 \mathrm{aA}$ & 207.9abA \\
\hline Cutting & $322.3 \mathrm{aB}$ & $286.6 \mathrm{bC}$ & 413.6bA & $191.0 \mathrm{aA}$ & $203.5 \mathrm{aA}$ & $175.8 \mathrm{bA}$ \\
\hline Free growth & $313.0 \mathrm{aB}$ & $332.7 \mathrm{aB}$ & $453.2 \mathrm{aA}$ & $208.5 \mathrm{aA}$ & $188.4 \mathrm{aA}$ & $237.6 \mathrm{aA}$ \\
\hline \multirow[t]{2}{*}{ CV (\%) } & & 6.99 & & & 20.49 & \\
\hline & \multicolumn{3}{|c|}{ Cellulose (g/kg) } & \multicolumn{3}{|c|}{ Lignin $(\mathrm{g} / \mathrm{kg})$} \\
\hline & \multicolumn{3}{|c|}{$\mathrm{DM}$ in vitro digestibility (g/kg) } & \multicolumn{3}{|c|}{$\mathrm{CP}$ in vitro digestibility (g/kg) } \\
\hline Grazing & $842.8 \mathrm{aA}$ & $825.4 \mathrm{aAB}$ & 793.6aB & $535.6 \mathrm{aA}$ & $526.6 \mathrm{aA}$ & $304.4 \mathrm{bB}$ \\
\hline Cutting & $854.3 \mathrm{aA}$ & $835.1 \mathrm{aAB}$ & $806.9 \mathrm{aB}$ & $520.6 \mathrm{aA}$ & 503.3aA & $289.4 \mathrm{bB}$ \\
\hline Free growth & $813.2 \mathrm{aA}$ & $800.9 \mathrm{aA}$ & $710.9 \mathrm{bB}$ & $547.9 \mathrm{aA}$ & $528.8 \mathrm{aA}$ & $431.1 \mathrm{aA}$ \\
\hline CV (\%) & & 5.84 & & & 23.62 & \\
\hline
\end{tabular}

Means followed by the same lowercase letter in row and uppercase letter in column do not differ by Tukey test at $5 \%$ probability.

CV - coefficient of variation; DM - dry matter; CP - crude protein. 
Grise et al. (2001) have pointed out that the increase of NDF content may be partly explained by the L/S ratio in the first collection date, when the plants showed a high L/S ratio and reduced NDF. Moreover, there was a NDF increase due to the L/S ratio decrease over time. For ADF, in the interaction of management $\times$ period, there was no difference $(\mathrm{P}>0.05)$ between managements during the first period. But, in the second and third periods, the values were higher in the absence of management. When periods were compared, the third period showed better results (Table 6). Fontaneli et al. (2009) worked on a dual-proposal of winter cereals that were cut for silage. The responses were quite inferior to those observed in this study for ADF in the UPF 18 white oat (230 g/kg DM).

Overall, there was an average increase in the content of cell wall constituents when the harvested forage was compared with the others in the third period. This fact can be explained by weather conditions that stimulated plants sprouting. This also caused an increase in temperature, which stimulated plants flowering as well as an increase in stem ratio and thus on cell wall constituents (Godoy \& Batista, 1992).

Results for hemicelluloses in the interaction of management $\times$ period showed no differences between managements during the first and second periods, but there was a higher response in the absence of management. And when periods were compared, no significant differences were observed (Table 6). Moreira et al. (2005) studied black and yellow oat genotypes for forage production. They recorded values similar to those obtained in this trial for hemicellulose in black oat $(217 \mathrm{~g} / \mathrm{kg})$.

The variable cellulose (Table 6), in the interaction of management $\times$ period, showed no difference between managements in the first and third periods; however, it was slightly lower for cutting and grazing managements in the second period. When periods were compared, this feature showed no significant difference. Moreira et al. (2007) worked on oat genotypes and also observed no significant differences between periods for the variable cellulose.

For the variable lignin, in the interaction of management $\times$ period, there was a significant difference $(\mathrm{P}<0.05)$ between managements only in the third period, with average values higher in the absence of management. And when periods were compared, the third one showed the highest average $(\mathrm{P}<0.05)$ for this feature (Table 6).

According to Van Soest (1994), decreased nutritive value of mature plants is due to lignification increase and a decrease in leaf/stem ratio (Table 6), which was also observed in the third period. Lacerda et al. (2006) obtained
$77 \mathrm{~g} / \mathrm{kg}$ lignin for whole UFRGS 7 yellow oat plant at 45 days, which was higher than those obtained in this trial (29.5; 42.7 and $56.2 \mathrm{~g} / \mathrm{kg}$ in the first, second and third periods, respectively).

Forage digestibility is differentiated by the plants maturity stadium, according to the changes that occur on their chemical composition. Dry matter in vitro digestibility (Table 6), in the interaction of management $\times$ period, showed no statistical difference between managements for the first and second periods. Thus, this feature was lower only in the absence of management in the third period. However, when comparing periods, this feature showed the highest results in the first period and the lowest ones for the third period. Moreira et al. (2007) worked with evaluations of black and yellow oat genotypes for forage production. They observed a DMIVD decrease for all genotypes, which is in accordance with the results obtained in this trial for IPR 126 white oat.

Values obtained for DMIVD were higher than those in some studies in the literature. Moreira et al. (2007) evaluated white oat of winter forage and triticale irrigated under grazing and the results were 780.4 and $673.5 \mathrm{~g} / \mathrm{kg}$ DMIVD. Grise et al. (2001) studied chemical composition and in vitro digestibility of the mixture IAPAR 61 oat and forage pea at different grazing heights. The authors recorded $697 \mathrm{~g} / \mathrm{kg}$ DMIVD at a height similar to this study $(18.2 \mathrm{~cm})$.

The highest forage DMIVD levels are probably associated with the maintenance of constant pasture growth due to a higher leaf area index with greater presence of young leaves and tillers during the study period (Grise et al., 2001).

Results for crude protein in vitro digestibility, in the interaction of management $\times$ period, showed significant differences between managements in the third period, with the highest value for absence of management. When evaluation periods were compared, the first and second periods showed higher results (Table 6). Values obtained for CP, NDF, ADF and DMIVD in this experiment confirmed the high nutritional quality of white oat.

\section{Conclusions}

The oat managed under free growth shows higher straw production, which favors the planting of annual summer crops, in spite of the low nutritional quality at the end of the cycle. Management heights do not affect nutritional quality or structural characteristics. The cutting of oat promotes plants tillering, but this does not result in increased dry matter production. Management, cutting and grazing systems do not affect the nutritional value of the forage. 


\section{References}

ASSOCIATION OF OFFICIAL ANALYTICAL CHEMISTS - AOAC. Official methods of analysis. 15.ed. Virginia: Arlington, 1990. $1117 \mathrm{p}$

BOLLER, W.; GAMERO, C.A. Estimativa dos custos econômicos e energéticos de sistemas de preparo e de manejo do solo para a cultura do feijão. Energia na Agricultura, v.12, n.2, p.26-38, 1997.

BORTOLINI, P.C; SANDINI, I.; CARVALHO, P.C.F. et al. Cereais de inverno submetidos ao corte no sistema de duplo propósito. Revista Brasileira de Zootecnia, v.33, n.1, p.45-50, 2004.

BORTOLINI, P.C.; MORAES, A.; CARVALHO, P.C.F. Produção de forragem e de grãos de aveia branca sob pastejo. Revista Brasileira de Zootecnia, v.34, n.6, p.2192-2199, 2005.

BREMM, C.; ROCHA, M.G.; FREITAS, F.K. et al. Comportamento ingestivo de novilhas de corte submetidas a estratégias de suplementação em pastagens de aveia e azevém. Revista Brasileira de Zootecnia, v.37, n.7, p.1161-1167, 2008.

BRISKE, D.D.; RICHARDS, J.H. Plant responses to defoliation: a physiologic, morphologic and demographic evaluation. In: BEDUNAH, D.J.; SOSEBEE, R.E. (Eds.) Wildland plants: physiological ecology and developmental morphology, 1995. p.635-710.

CECATO, U.; RÊGO, F.C.A.; GOMES, J.A.N. et al. Produção e composição química em cultivares e linhagens de aveia (Avena spp.). Acta Scientiarum, v.23, n.4, p.775-780, 2001.

DEMETRIO, J.V. Rendimento de biomassa de genótipos de aveia submetidos a diferentes épocas de corte no sistema de integração lavoura pecuária. 2009. 74f. Dissertação de (Mestrado Agronomia) - Universidade Estadual do Oeste do Paraná, Marechal Cândido Rondon.

EMPRESA BRASILEIRA DE PESQUISA AGROPECUÁRIA EMBRAPA. Sistema brasileiro de classificação de solos. Brasília, 2006. p.412.

FEROLLA, F.S.; VÁSQUEZ, H.M.; COELHO DA SILVA, J.F. et al. Composição bromatológica e fracionamento de carboidratos e proteínas de aveia preta e triticale sob corte e pastejo. Revista Brasileira de Zootecnia, v.37, n.2 p.197-204, 2008.

FLOSS, E.L.; FONTANELI, R.S.; KONRAD, E. Rendimento de forragem e grãos de aveia (Avena $\mathrm{sp}$ ) sob diferentes freqüências de corte. In: Resultados de pesquisa de aveia obtidos em 1981. Passo Fundo: Universidade de Passo Fundo/Faculdade de Agronomia, 1985. p.91-101. (Boletim de Pesquisa, 8).

FONTANELI, R.S.; FONTANELI, R.S.; SANTOS, H.P. et al. Rendimento e valor nutritivo de cereais de inverno de duplo propósito: forragem verde e silagem ou grãos. Revista Brasileira de Zootecnia, v.38, n.11, p.2116-2120, 2009.

GODOY, R.; BATISTA, L.A.R. Avaliação do potencial de produção de grãos de germoplasma de aveia forrageira, na região de São Carlos, SP. Pesquisa Agropecuária Brasileira, v.27, n.9, p.1253-1257, 1992.

GOMIDE, J.A. Manejo de pastagem para a produção de leite. In: SIMPÓSIO INTERNACIONAL DE FORRAGICULTURA. In: REUNIÃO ANUAL DA SOCIEDADE BRASILEIRA DE ZOOTECNIA, 31., 1994, Maringá. Anais... Maringá: EDUEM, 1994. p.141-168.

GRISE, M.M.; CECATO, U.; MORAES, A. et al. Avaliação da composição química e da digestibilidade in vitro da mistura aveia IAPAR 61 (Avena strigosa Schreb.) + ervilha forrageira (Pisum arvense L.) em diferentes alturas sob pastejo. Revista Brasileira de Zootecnia, v.30, n.3, p.659-665, 2001.

HOLDEN, L.A. Comparison of methods of in vitro matter digestibility for ten feeds. Journal Dairy Science, v.82, n.8, p.1791-1794, 1999.

IDO, O.T. Efeito de diferentes ofertas de forragem sobre a produção e a qualidade de um pasto de azevém (Lolium multiflorum Lam) associada com leguminosas de inverno, na Região Sul do Paraná. 1997. 81f. Dissertação (Mestrado em Agronomia) - Universidade Federal do Paraná, Curitiba.
INSTITUTO AGRONÔMICO DO PARANÁ - IAPAR. Cartas Climáticas do Paraná. 2006. Available at: <http://200.201.27.14/ Site/Sma/Cartas_Climaticas/Classificação_Climaticas.htm>. Accessed on: Sept. 3, 2008.

KLUTHCOUSKI, J.; YOKOYAMA, L.P. Opções de integração lavoura-pecuária. In: KLUTHCOUSKI, J.; STONE, L.F.; AIDAIR, H. (Eds.). Integração lavoura pecuária. Santo Antônio de Goiás: Embrapa Arroz e Feijão, 2003. p.131-181.

LACERDA, R.S.; GOMIDE, C.A.; FUKUSHIMA, R.S. et al. Lignin concentration in oat (Avena byzantina L.) aerial part as measured by analytical methods. Brazilian Journal Research Animal Science, v.43, n.3, p.400-407, 2006.

LANGER, R.H.M. Tillering in herbage grasses. Herbage Abstract, v.35, n.3, p.141-148, 1963.

MELLO, A.C.L.; PEDREIRA, C.G.S. Respostas morfológicas do capim tanzânia (Panicum maximum Jacq. cv. Tanzânia) Irrigado à intensidade de desfolha sob lotação rotacionada. Revista Brasileira de Zootecnia, v.33, n.2, p.282-289, 2004.

MOREIRA, A.L.; REIS, R.A.; RUGGIERI, A.C. Avaliação de forrageiras de inverno irrigadas sob pastejo. Ciência Agrotecnológica, v.31, n.6, p.1838-1844, 2007.

MOREIRA, A.L.; RUGGIERI, A.C.; REIS, R.A. et al. Avaliação da aveia preta e de genótipos de aveia amarela para produção de forragem. Ars Veterinaria, v.21, p.175-182, 2005.

MUNDSTOCK, C.M. Manejo para duplo propósito. In: MUNDSTOCK, C.M. (Ed.) Planejamento e manejo integrado da lavoura de trigo. Porto Alegre, 1999. p.207-210.

NAKAGAWA, J.; CAVARIANI, C.; MACHADO, J.R. Adubação nitrogenada no perfilhamento da aveia preta em duas condições de fertilidade do solo. Pesquisa Agropecuária Brasileira, v.35, n.6, p.1071-1080, 2000.

PRIMAVESI, A. C.; PRIMAVESI, O.; CANTARELlA, H.; et al. Resposta da aveia branca à adubação em latossolo vermelhoamarelo em dois sistemas de plantio. Revista Brasileira de Zootecnia, v.33, n.1, p.79-86, 2004.

PRIMAVESI, A.C.; PRIMAVESI, O.; CHINELLATO, A. et al. Indicadores de determinação de cortes de cultivares de aveia forrageira. Scientia Agricola, v.58, n.1, p.79-89, 2001.

REICHARDT, J.; MAUAD, M.; WOLSCHIK, D. Adubação nitrogenada aplicada no início do perfilhamento da aveia branca. Agrarian, v.1, n.2, p.71-81, 2008.

REIS, J.C.L.; COELHO, R.W.; PRIMO, A.T. Caracterização e avaliação de germoplasma de forrageiras em terras baixas. Capão do Leão: EMBRAPA-CPATB, 1992. 28p.

ROCHA, M.G.; PEREIRA, L.E.T.; SCARAVELLI, L.F.B. et al. Produção e qualidade de forragem da mistura de aveia e azevém sob dois métodos de estabelecimento. Revista Brasileira de Zootecnia, v.36, n.1, p.7-15, 2007.

ROSO C.; RESTLE J.; SOARES A.B. et al. Produção e qualidade de forragem da mistura de gramíneas anuais de estação fria sob pastejo contínuo. Revista Brasileira de Zootecnia, v.28, n.3, p.459-467, 1999.

SARAIVA, O.F.; TORRES, E. Estimação da cobertura do solo por resíduos culturais. Londrina: Embrapa-CNPSO, 1993. 4p.

SIMON, J.C.; LEMAIRE, G. Tillering and leaf area index in grasses in the vegetative phase. Grassland Forage Science, v.42, p.373-380, 1987.

SILVA, D.J.; QUEIROZ, A.C. Análise de alimentos: métodos químicos e biológicos. Viçosa, MG: UFV, 2006. 235p.

TILLEY, J.M.A.; TERRY, R.A. A two stage technique for in vitro digestion of forages crops. Journal of the British Grassland Society, v.18, p.104-111, 1963.

VAN SOEST, P.J.; ROBERTSON, J.B.; LEWIS, B.A. Methods for dietary fiber, neutral detergent fiber, and nonstarch polysaccharides in relation to animal nutrition. Journal of Dairy Science, v.74, n.1, p.3583-3597, 1991.

VAN SOEST, P.J. Nutritional ecology of the ruminant. 2.ed. New York: Cornell University, 1994. 476p. 